098

Received: July 6, 2009

Accepted: November 17, 2009

\title{
THE UTILIZATION OF PROBIOTICS AS A WAY TO IMPROVE HUMAN AND ANIMAL GUT HEALTH
}

\author{
Etleva Veizaj-Delia ${ }^{1}$, Rudina Pirushi ${ }^{2}$

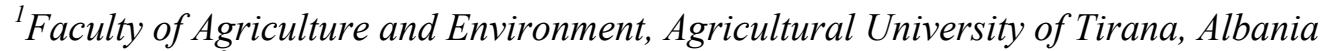 \\ ${ }^{2}$ University of Tirana, Faculty of Nursing. Tirana, Albania \\ etlevade@yahoo.com
}

\begin{abstract}
Probiotics have been defined by Collins and Gibson (1999) as "a live microbial feed supplement which beneficially affects the host animal by improving its intestinal balance". There is a relatively large volume of literature that supports the use of probiotics to prevent or treat intestinal disorders. Currently, the best studied probiotics are the lactic acid bacteria, particularly Lactobacillus sp and Bifidobacterium sp. The mucosal surface of the intestinal tract represents the largest interface between the body and its environment. An effective local immune is necessary to protect the organism against the invasion of noxious antigens and microbes. No other organ of the body harbors more immune cells than the gut -associated lymphoid tissue (GALT), and a tremendous amount of antibodies is secreted into the intestinal lumen to neutralize and exclude harmful antigens. The numerous studies have reported immune stimulating abilities for different bacterial species. For example, in vitro cytokine production of macrophages was stimulated by Bifidobacteria (Marin et al., 1997). Bifidobacterium longum as well as several other lactic acid bacteria have been found to increase the total amount of intestinal IgA. Lactobacillus casei was reported to have immune adjuvant activity (Perdigon et al., 1989) and Lactobacillus plantarum was shown to increase antibody production against Escherichia coli.
\end{abstract}

Key words: probiotics; Lactobacillus sp,; intestinal microbial balance; gut health

\section{КОРИСТЕЊЕ НА ПРОБИОТИЦИ КАКО НАЧИН ЗА ПОДОБРУВАЊЕ НА ЗДРАВЈЕТО НА ХУМАН И АНИМАЛЕН ДИГЕСТИВЕН ТРАКТ}

Пробиотиците се дефинирани од Collins и Gibson (1999) како „жив микробиолошки хранлив додаток со корисен ефект кај домашните животни преку подобрување на интестиналната рамнотежа“. Релативно е голем волуменот на литературата во која се поддржува примената на пробиотици за превентива или третирање при цревни нарушувања. Општо земено, најдобро испитувани пробиотици се: млечнокиселинските бактерии, посебно Lactobacillus sp. и Bifidobacterium sp. Мукозната површина на интестиналниот тракт претставува обемна внатрешна површина помеѓу телото и неговата средина. Делотворниот локален имунитет е неопходен за заштита на организмот од навлегувањето на штетните антигени и микроби. Ниту еден орган во телото не содржи повеќе имуни клетки од стомакот - лимфоидните ткива на цревата и огромна количина антитела кои се лачат во интестиналниот тракт за да ги неутрализираат и исфрлуваат штетните антигени. Многубројните истражувања укажуваат на имунолошката стимулативна моќ на различните видови бактерии. На пример, продукцијата ин витро на цитокинин на макрофагите беше стимулирана со Bifidobacteria (Marin et al., 1997). Најдено е дека Bifidobacterium longum, исто како други млечнокиселински бактерии, го зголемува вкупното количество на интестиналната IgA. Се покажа дека Lactobacilluc casei предизвикува дополнителна имуна активност (Perdigon et al., 1989) и дека Lactobacillus plantarum влијае за зголемена продукција на антитела против Escherihia coli.

Клучни зборови: пробиотици; Lactobacilus sp.; интестинална микробиолошка рамнотежа; здрав дигестивен тракт

\section{PROBIOTICS}

The mucosal surface of the intestinal tract represents the largest interface between the body and its environment. An effective local immunuty is necessary to protect the organism against the invasion of noxious antigens and microbes. No other organ of the body harbours more immune 
cells than the gut - associated lymphoid tissue (GALT), and a tremendous amount of antibodies is secreted into the intestinal lumen to neutralize and exclude harmful antigens. In numerous studies it has been shown that bacterial colonization influences the function of immune cells belonging to the GALT and even affects the systemic immune system (Travnicek et al., 1989). Immune suppression has been observed after associating gerfree rodents with defined bacterial species (Scharek et al., 2000). The numerous studies have reported immune stimulating abilities for different bacterial species. For example, in vitro cytokine production of macrophages was stimulated by Bifidobacteria (Marin et al., 1997). Bifidobacterium longum as well as several other lactic acid bacteria have been found to increase the total amount of intestinal $\operatorname{IgA}$ (Vitini et al., 2001). Lactobacillus casei was reported to have immunoadjuvant activity (Perdigon et al., 1991) and Lactobacillus plantarum was shown to increase antibody production against $E s$ cherichia coli. Induction of cytokine profiles by lactobacilli is likely to be strain-dependent (Maassen et al., 2000). Probiotic treatment using Bifidobacterium lactis HN019 reduced weanling diarrhea associated with rotavirus and Escherichia coli infection in a piglet model (Shu et al., 2001). Information from studies is also available about the age-dependent development of different immune cells in the intestine of the newborn and adult pigs (Vega-Lopez et al., 2001).

\section{EFFICIENCY OF PROBIOTICS IN FARM ANIMALS}

Since probiotics are discussed as alternatives to antimicrobial growth promoters their impact on performance of farm animals is of prime interest. For authorization of microorganisms as feed additives it is also required to show significant effects on performance data (Simon et al., 2003). Most experiments were performed with piglets. According to a litterature review in Tuschy (1986) no significant positive effects could be found from the hitherto results with piglets and fattening pigs. Later, the evaluation of studies conducted with raising piglets drew a different picture (Freitag et al., 1998). Tuschy (1986) used the strict criteria of biostatistics and only significant effects were documented. Today, trends without statistical significance are also considered as a positive effect (Simon et al., 2003). It is obvious that majority of the experiments show trends toward positive effects, however the significance level of $p \leq 0.05$ was reached only in $5 \%$ of experiments. In a trial with 90 treated and 90 untreated Bacillus cereus preparation weaned piglets, the probiotic treated animals gained $7 \%$ more live weight during 6 weeks after weaning with a reduced feed conversion ratio of $2.4 \%$. Both results were not significant (Jadamus et al., 2001). This points towards a high variation in the response of the individual animals to this type of feed additives (Simon et al., 2003). Reduction of diarrhea by probiotics was studied frequently, because diarrhea is the main problem of piglets during the first weeks after weaning with utmost importance for production (Simon et al., 2003).

With regard to the evaluation of animal performance, the same conclusion can be drawin for experiments with fattening chicken (Simon et al., 2001). This is also reflected by a series of experiments with turkey, poultry under field conditions using three probiotics (Männer et al., 2002). Again none of the effects in performance were significant, on average weight gain was improved by $1.5 \%(+0.1$ to +3.8$)$ and feed conversion by $-2 \%$ $(-7$ to -3.5$)$. A further observation was a more pronounced effect of additive during weeks 1 to 5 . However again no significance was seen in the period's week 1 plus 2 and 3 to 5 , respectively (Simon et al., 2003).

Simon et al. (2003) concluded that the inconsistency of the effectiveness of a feed additive is of course not convenient, but on the other hand comprehensible for this type of feed additive. Probiotics do not act like essential nutrients in term of a clear dose response until the requirements are met. Due to the complexity of intestine, individual variations of animals to probiotic inclusion may be the rule and not the exception. Considering this concept the range between no effect and significant effects seems to be reasonable.

The morphological changes in the bovine intestine are more complex than in mammals or poultry and thus the potential benefits of probiotic supplementation may also be greater (Wallace and Newbold, 1992).

Huber (1997) summarized the effects of probiotic feeding to baby calves and next to greater feed intake and improved weight gain the reduction of diarrhea was one of the most prominent results observed. The reduction of pathogenic Escherichia coli $\mathrm{O} 157: \mathrm{H} 7$ has also been reported by 
administering a probiotic preparation containing Streptococcus bovis, Lactobacillus gallinarum, Saccharomyces cerevisiae as active ingredients, respectively (Ohya et al., 2000). In a feeding trial with two different probiotic preparations (Enterococcus faecium, Bacillus cereus), added to the milk replacer for calves (50 to $85 \mathrm{~kg}$ body weight), a non significant increase in live weight gain was observed, together with a significant decrease of the frequency of diarrhea (Simon et al., 2001). Although in ruminants the addition of some bacterial additives and Aspergillus oryzae have shown to have beneficial effects, all authorised microbial feed additives for dairy cattle and with one exception for cattle for fattening are Saccharomyces cerevisiae strain. The actual knowledge on their mode of action effectiveness was recently reviewed by Newbold (2003). Newbold concluded: "Research on microbial feed additives for ruminants are often frustrating, because responses are small and highly variable" and claimed that the situation will improve as progress is made in defining the action of these additives.

\section{MECHANISMS OF ACTION}

There are many proposed mechanisms by which probiotics may protect the host from intestinal disorders. The sum of all processes by which bacteria inhibit colonization by other strains is called colonization resistance. Much work remains to classify the mechanisms of action of particular probiotics against particular pathogens. In addition, the same probiotic may inhibit different pathogens by different mechanisms. A brief description of mechanisms is listed below by which probiotics may protect the host against intestinal disease.

\section{PRODUCTION OF INHIBITORY SUBSTANCES}

Probiotic bacteria produce a variety of substances that are inhibitory to both gram-positive and gram-negative bacteria. These inhibitory substances include organic acids, hydrogen peroxide and bacteriocins. These compounds may reduce not only the number of viable cells but may also affect bacterial metabolism or toxin production.

\section{BLOCKING OF ADHESION SITES}

Competitive inhibition for bacterial adhesion sites on intestinal epithelial surfaces is another mechanism of action for probiotics (Goldin et al., 1992). Consequently, some probiotic strains have been chosen for their ability to adhere to epithelial cells.

\section{COMPETITION FOR NUTRIENTS}

Competition for nutrients has been proposed as a mechanism for probiotics. Probiotics may utilize nutrients otherwise consumed by pathogenic microorganisms. However, the evidence that this occurs in vivo is lacking.

\section{DEGRADATION OF TOXIN RECEPTOR}

The postulated mechanism by which $S$. boulardii protects animals against $C$. difficile intestinal disease is through degradation of the toxin receptor on the intestinal mucosa (Castagliuolo et al., 1999).

\section{STIMULATION OF IMMUNITY}

Recent evidence suggests that stimulation of specific and nonspecific immunity may be another mechanism by which probiotics can protect against intestinal disease (Pouwels et al., 1996). For example, peroral administration of Lactobacillus GG during acute rotavirus diarrhea is associated with an enhanced immune response to rotavirus (Kaila et al., 1992). This may account for the shortened course of diarrhea seen in treated patients. The underlying mechanisms of immune stimulation are not well understood, but specific cell wall components or cell layers may act as adjuvants and increase humoral immune responses.

\section{PROBIOTIC TREATMENT OF INFECTIOUS DIARRHEA}

It is very difficult to perform a critical analysis of studies that have examined the use of probiotics for the treatment and/or prevention of infectious diarrhea. First, there are many etiological agents that cause infectious diarrhea (e.g., Shig- 
ella, Salmonella, C. difficile, rotavirus, enterotoxigenic E. coli), and the majority of the studies do not attempt to define the cause of the diarrhea. In addition, many of the studies involved only a small number of patients. Two of the more common types of infectious diarrheal diseases will be described in greater detail below, i.e., traveler's diarrhea and rotavirus diarrhea.

\section{TRAVELER'S DIARRHEA}

The incidence of diarrhea in travelers to foreign countries varies from 20 to $50 \%$ depending on the origin and the destination of the traveler, as well as the mode of travel. Although various infectious agents can cause traveler's diarrhea, enterotoxigenic $E$. coli is the most common. Even small attacks can interrupt a holiday, and the traveling public has a great interest in medications that could be used to prevent traveler's diarrhea. Thus, a safe, inexpensive and effective drug against traveler's diarrhea would have important public health implications. Several probiotics have been examined for their ability to prevent traveler's diarrhea, including Lactobacillus, Bifidobacterium, Streptococcus and Saccharomyces (Hilton et al., 1997). These studies have involved several different groups of travelers such as Finnish travelers to Turkey, American travelers to Mexico, British soldiers to Belize and European travelers to Egypt. The results from these studies have been extremely variable. For example, in the study of Finnish travelers to Turkey, the travelers had two different destinations (Oksanen et al., 1990). In one destination, Lactobacillus GG provided protection against travelers' diarrhea but failed to protect travelers at the other destination. Different etiologic agents may have involved in these two locations, but this possibility was not examined.

\section{ROTAVIRUS DIARRHEA}

Rotaviruses are a significant cause of infant morbidity and mortality, particularly in developing countries (Majamaa et al., 1995). The principal means of treatment is oral rehydration, although an effective vaccine that should decrease dramatically the health impact of rotavirus infections has recently become available. Lactobacillus has demonstrated some promise as a treatment for rotavirus infection (Majamaa et al., 1995). Isolauri et al.
(1991) treated 74 children (ages 4-45 mo) with diarrhea with either Lactobacillus GG or placebo. Approximately $80 \%$ of the children with diarrhea were positive for rotavirus. The investigators demonstrated that the duration of diarrhea was significantly shortened (from 2.4 to $1.4 \mathrm{~d}$ ) in patients receiving Lactobacillus GG. The effect was even more significant when only the rotavirus-positive patients were analyzed.

\section{HELICOBACTER PYLORI GASTROENTERITIS}

H. pylori has recently been shown to be an important etiologic agent of chronic gastritis as well as gastric and duodenal ulcers. It has also been postulated that chronic H. pylori infection leads to stomach carcinoma. Lactobacillus has been shown to be antagonistic to H. pylori both in vitro and in a gnotobiotic murine model (Aiba et al., 1998,). The results of the few studies with Lactobacillus that have been performed in humans are conflicting, with some showing modest protection and others showing no protection.

\section{HEPATIC ENCEPHALOPATHY}

Hepatic encephalopathy is a neurologic disorder caused by increased blood levels of ammonia. Ammonia is produced in the intestine by the action of bacterial ureases. Ammonia is absorbed and, in healthy individuals, is detoxified by the liver. However, in patients with liver failure, the blood concentration of ammonia can reach toxic levels. Investigators have postulated that it may be possible to use probiotics to decrease intestinal urease activity. For example, patients treated with L. acidophilus and neomycin show a greater decrease in fecal urease activity than patients treated with neomycin alone (Scevola et al., 1989). The decreased fecal urease activities correspond to lower serum ammonia levels and improvements in the clinical status of patients.

\section{HIV/AIDS DIARRHEA}

Diarrhea is a very serious consequence of human immunodeficiency virus (HIV) infection. The etiology of this diarrhea is frequently unknown and there are no effective treatment mo- 
dalities. However, S. boulardii was recently used to treat $33 \mathrm{HIV}$ patients with chronic diarrhea (Born et al. 1993). In these double-blind studies, $56 \%$ of patients receiving $S$. boulardii had resolution of diarrhea compared with only $9 \%$ of patients receiving placebo.

\section{SUCRASE-ISOMALTASE DEFICIENCY}

Sucrase-isomaltase deficiency is the most frequent primary disaccharidase deficiency seen in humans. It is an inherited condition that leads to malabsorption of sucrose. The resulting bacterial fermentation of the sucrose leads to an accumulation of hydrogen in the colon, producing diarrhea, abdominal cramps and bloating. A sucrosefree diet causes disappearance of symptoms. However, not all patients will follow such a diet. Harms et al. (1987) used Saccharomyces cerevisiae to treat eight children with sucrase-isomaltase deficiency. These investigators demonstrated that in children given sucrose followed by $S$. cerevisiae, there was an improvement in both their hydrogen breath test and gastrointestinal symptoms. The investigators postulated that $S$. cerevisiae was supplying the missing enzymes.

\section{LACTOSE INTOLERANCE}

People throughout the world suffer from a congenital deficiency of the enzyme $b$-galactosidase. This deficiency results in an inability to digest and absorb lactose. Bacteria metabolize the lactose and the resulting by-products cause abdominal cramping, bloating, diarrhea and nausea. Lactase-positive strains of bacteria (e.g., Lactobacillus, Bifidobacterium and Streptococcus) are commonly added to pasteurize dairy products to increase digestibility of the lactose present in the dairy product (Pettoello et al., 1989). There are two probable mechanisms by which the addition of these bacteria is beneficial, i.e. the reduction of lactose in the dairy product through fermentation and the replication of the probiotic in the gastrointestinal tract, which releases lactase.

\section{INFLAMMATORY BOWEL DISEASE}

There are two inflammatory bowel diseases, Crohn's disease and ulcerative colitis; their etiolo- gies are unknown but may be related to disturbances of the intestinal microbial flora (Fabia et al., 1993). Crohn's disease is an idiopathic inflammatory bowel disease that occurs from the mouth to the anus, although the terminal ileum is a most common site of disease. The most common clinical manifestation of ulcerative colitis is an inflammation of the colon. No specific treatment is available for either disease. Kruis et al. (1997) examined the Nissle strain of nonpathogenic E. coli (serotype O6:K5:H1) for its ability to prevent relapses of ulcerative colitis. Preliminary results look promising and suggest that this may be another option for maintenance therapy of ulcerative colitis.

\section{POUCHITIS}

Pouchitis is a complication of ileal reservoir surgery occurring in $10-20 \%$ of the patients who undergo surgical treatment for chronic ulcerative colitis. Bacteria overgrow in the pouch, resulting in degradation of the mucus overlaying the epithelial cells (Ruseler-Van Embden et al., 1995). This results in inflammation and symptoms that include bloody diarrhea, lower abdominal pain and fever. Investigators have postulated that Lactobacillus GG may be an effective therapeutic agent for pouchitis because it does not demonstrate mucusdegrading properties (Ruseler-Van Embden et al., 1995).

\section{IRRITABLE BOWEL SYNDROME}

Irritable bowel syndrome is characterized by chronic, recurrent pain that occurs primarily during childhood. There is no specific treatment of this condition. However, a small, doubleblind, placebo-controlled, crossover study in Poland demonstrated a slight but significant reduction in the severity of abdominal pain in individuals receiving L. plantarum (Niedzielin and Kordecki, 1996).

\section{SMALL BOWEL BACTERIAL OVERGROWTH}

Overgrowth of bacteria in the small intestine can have many causes, including blind loops, stenosis of the intestine, diverticula and motility disorders. Symptoms of small bowel overgrowth are frequently chronic and relapsing. Response to 
antibiotic treatment is often inadequate or incomplete. Surgical treatment is occasionally possible, but in many cases the underlying cause is not accessible for permanent treatment. Limited studies have suggested that L. plantarum and Lactobacillus GG may be helpful in eliminating the symptoms of small bowel bacterial overgrowth (Vanderhoof et al., 1998).

\section{ENTERAL FEEDING - ASSOCIATED DIARRHEA}

Patients receiving nasogastric tube feeding frequently develop diarrhea. The mechanism of the diarrhea is not known, but investigators postulate that entered feeding causes changes in normal flora that result in altered carbohydrate metabolism and subsequent diarrhea (Guenter et al., 1991). Two separate studies (both placebo-controlled and double blind) demonstrated a significant reduction in diarrhea in these patients when they were given $S$. boulardii (Tempe et al., 1983).

\section{CARCINOGENESIS}

Evidence is accumulating that the normal intestinal flora can influence carcinogenesis by producing enzymes that transform precarcinogens into active carcinogens. These enzymes include glycosidase, $b$-glucuronidase, azoreductase and nitroreductase (Pedrosa et al., 1995). There is some evidence that selected microorganisms may actually protect the host from this carcinogenic activity. There are three postulated mechanisms for this protection as follows:

1) The probiotic may inhibit the bacteria that are responsible for converting precarcinogens into carcinogens;

2) Animal studies have shown that some probiotics inhibit tumor cell formation directly; and

3) Some bacteria have been shown to bind and/or inactivate carcinogens (Orrhage et al., 1994). Human volunteers receiving either $L$. acidophilus or $L$. casei have reduced levels of enzymes that convert.

\section{REFERENCES}

[1] Adam, J., Barret, A. \& Barret-Bellet C. (1977): Essais cliniques controles en double insu de l'ultra-levure lyophilise: etude multicentrique par 25 medecins de 388 cases. Gaz. Med. Fr. 84: 2072-2078.
[2] Born, P., Lersch, C., Zimmerhackl, B. \& Classen, M. (1993): The Saccharomyces boulardii therapy of HIV-associated diarrhea (letter). Dtsch. Med. Wochenschr. 118: 765 .

[3] Castagliuolo, I., Riegler, M. F., Valenick, L., LaMont, J. T. \& Pothoulakis, C. (1999): Saccharomyces boulardii protease inhibits the effects of Clostridium difficile toxins $\mathrm{A}$ and $\mathrm{B}$ in human colonic mucosa. Infect. Immun,. 67: 302-307.

[4] Collins, M. D., and G. R. Gibson. (1999): Probiotics, prebiotics and synbiotics: approaches for modulating the microbial ecology of the gut. Am. J. Clin. Nutr. 69 (Suppl):1052S-1057S.

[5] Fabia, R., Ar'Rajab, A., Johansson, M. L., Andersson, R., Willen, R., Jeppsson, B., Molin, G. \& Bengmark, S. (1993): Impairment of bacterial flora in human ulcerative colitis and experimental colitis in the rat. Digestion, 54: 248-255.

[6] Freitag, M., Hensche, H-U., Schulte-Sienbeck, H and Reichelt, B. (1998): Kritische Betrachtung des Einsatzes von Leistungsförderern in der Tierernährung. Forschungsberichte der Universität Paderborn, Nr. 8.

[7] Goldin, B. R., Gorbach, S. L., Saxelin, M., Barakat, S., Gualtieri, L. \& Salminen, S. (1992): Survival of Lactobacillus species (strain GG) in human gastrointestinal tract. Dig. Dis. Sci. 37: 121-128.

[8] Guenter, P. A., Settle, R. G., Perlmutter, S., Marino, P. L., DeSimone, G. A. \& Rolandelli, R. H. (1991): Tube feeding-related diarrhea in acutely ill patients. J. Parent. Enteral Nutr. 15: 277-280.

[9] Harms, H. K., Bertele-Harms, R. M. \& Bruer-Kleis, D. (1987): Enzyme-substitution therapy with the yeast Saccharomyces cerevisiae in congenital sucrase-isomaltase deficiency. N. Engl. J. Med. 316: 1306-1309.

[10] Hilton, E., Kolakowski, P., Singer, C. \& Smith, M. (1997): Efficacy of Lactobacillus GG as a diarrheal preventive in travelers. J. Travel Med. 4: 41-43.

[11] Huber, J. T. (1997): Probiotics in cattle. In: Probiotics 2Applications and practical aspects, pp.162-180. (Fuller, R. ed.), Chapman and Hall, London.

[12] Isolauri, E., Juntunen, M., Rautanen, T., Sillanaukee, P. \& Koivula, T. (1991): A human Lactobacillus strain (Lactobacillus casei sp. strain GG) promotes recovery from acute diarrhea in children. Pediatrics, 88: 90-97.

[13] Jadamus A. (2001): Untersuchungen zur Wirksamkeit und Wirkungsweise des sporenbildenden Bacillus cereus var. toyoi im Verdauungstrakt von Broilern und Ferkel. Degree Dissertation, Free University, Berlin.

[14] Kaila, M., Isolauri, E., Soppi, E., Virtanen, E., Laine, S. \& Arvilommi, H. (1992): Enhancement of the circulating antibody secreting cell response in human diarrhea by a human Lactobacillus strain. Pediatr. Res. 32: 141-144.

[15] Kruis, W., Schutz, E., Fric, P., Fixa, B., Judmaier, G. \& Stolte, M. (1997): Double-blind comparison of an oral Escherichia coli preparation and mesalazine in maintaining remission of ulcerative colitis. Aliment. Pharmacol. Ther. 11: 853-858.

[16] Maassen, C. B., Van Holten-Neelen, C., Balk, F., Den Bak-Glashouwer, M. J., Leer, R. J., Laman, J. D., Boersma, W. J. and Claassen, E (2000): Strain-dependent induction of cytokine profiles in the gut by orally admin- 
istered Lactobacillus strains. Vaccine 18, 26132623.

[17] Majamaa, H., Isolauri, E., Saxelin, M. \& Vesikari, T. (1995): Lactic acid bacteria in the treatment of acute rotavirus gastroenteritis. J. Pediatr. Gastroenterol. Nutr. 20: $333-338$.

[18] Männer K., Jadamus A., Vahjen W., Frackenpohl U., Simon O. (2002): Effekte probiotischer Zusätze auf Leistungsparameter und intestinale Mikroflora. Proc. 7. Tagung, Schweine und Geflügelernährung, 78-80.

[19] Marin, M. L., Lee, J. H., Murtha, J., Ustunol, Z and Petka J. J. (1997): Differential cytokine production in clonal macrophage and T-cell lines cultured with bifidobacteria. Journal of Dairy Science, 80, 2713-2720.

[20] Newbold, C. J. (2003): Probiotics. Principes for use in ruminant nutrition. In van Vuuren and B. Rochet: Role of probiotics in animal nutrition and their link to the demands of European consumers, ID-Lelystad. 29-39.

[21] Niedzielin, K. \& Kordecki, H. (1996): Therapeutic usefulness of "ProViva" solution in the treatment of irritable bowel syndrome and hemorrhoids. Presented at the Symposium of Gastroenterology, Heiligenstadt, Germany.

[22] Ohya, T., Marubashi, T., and Ito, H. (2000): Significance of fecal volatile fatty acids in shedding of Escherichia coli $\mathrm{O} 157$ from calves: experimental infection and preliminary use of probiotic product. Journal of Veterinary Medical Science, 62, 1151-1155.

[23] Oksanen, P. J., Salminen, S., Saxelin, M., Hamalainen, P., Ihantola-Vormisto, A., Muurasniemi-Isoviita, L., Nikkari, S., Oksanen, T., Porsti, I., \& Salminen, E. (1990): Prevention of travellers' diarrhea by Lactobacillus GG. Ann. Med. 22: 53-56.

[24] Orrhage, K., Sillerstrom, E., Gustafsson, J. A., Nord, C. E. \& Rafter, J. (1994): Binding of mutagenic heterocyclic amines by intestinal and lactic acid bacteria. Mutat. Res. 311: 239-248.

[25] Pedrosa, M. C., Golner, B. B., Goldin, B. R., Barakat, S., Dallal, G. E. \& Russell, R. M. (1995): Survival of yogurtcontaining organisms and Lactobacillus gasseri (ADH) and their effect on bacterial enzyme activity in the gastrointestinal tract of healthy and hypochlorhydric elderly subjects. Am. J. Clin. Nutr. 61: 353-359.

[26] Perdigon, G., Alvarez, S., de Ruiz, P and Holgado, A. (1991): Immunoadjuvant activity of oral Lactobacillus casei: influence of dose on the secretory immune response and protective capacity in intestinal infections. Journal of Dairy Research, 58, 485-496.

[27] Pettoello, M. M., Guandalini, S., Ecuba, P., Corvino, C. \& di Martino, L. (1989): Lactose malabsorption in children with symptomatic Giardia lamblia infection: feasibility of yoghurt supplementation. J. Pediatr. Gastroenterol. 9: 295-230.
[28] Pouwels, P. H., Leer, R. J. \& Boersma, W. J. (1996): The potential of Lactobacillus as a carrier for oral immunization: development and preliminary characterization of vector systems for targeted delivery of antigens. J. Biotechnol. 44: 183-192.

[29] Ruseler-Van Embden, J.G.H., Hazenberg, M. P., Van Lieshout, L.M.C. \& Schouten, W. R. (1995): Instability of the pouch flora: cause of pouchitis? Microecol. Ther. 23: 81-88.

[30] Scevola, D., Zambelli, A., Concia, E., Perversi, L. \& Candiani, C. (1989) Lactitol and neomycin: monotherapy or combined therapy in the prevention and treatment of hepatic encephalopathy? Clin. Ther. 129: 105-111.

[31] Scharek, L., Hartmann, L., Heinevette, R. L., and Blaut, M (2000): Bifidobacterium adolescentismodulates the specific immune response to another human gut bacterium, Bacteroides thetaiotaomicron, in gnotobiotic rats. Immunobiology, 202, 429-441.

[32] Shu. Q., Qu. F., and Gill H S., (2001): Probiotic treatment using Bifidobacterium lactis HNO19 reduces weanling diarrhea associated lymphoid tissue in neonatal swine. Immunological Methods, 241, 185-199.

[33] Simon et al (2003): Micro-organisms as feed additivesProbiotics. Proceedings of the $9^{\text {th }}$ International Symposium in Digestive Physiology in Pigs. Vol 1, 295-318.

[34] Simon O, Jadamus A, Vahjen W. (2001): Probiotic feed additives - effectiveness and expected modes of action. $J$. Anim. Sci. 10 Supp 11: 51-67

[35] Tempe, J. D., Steidel, A. L., Blehaut, H., Hasselmann, M., Lutun, P. \& Maurier, F. (1983) Prevention of diarrhea administering Saccharomyces boulardii during continuous enteral feeding. Sem. Hop. 59: 1409-1412.

[36] Travnicek, J., Mandel, Trebichavsky, I., and Talafantova, M. (1989): Immunological state of adult germfree miniature Minnesota pigs. Folia Microbiologia. 34, 157-164.

[37] Tuschy, D. (1986): Verwendung von Probiotika' als Leistungsförderer in der Tierernährung. Übersichten Tierernährung, 14, 157-178.

[38] Vanderhoof, J. A., Young, R. J., Murray, N. \& Kaufman, S. S. (1998): Treatment strategies for small bowel bacterial overgrowth in short bowel syndrome.

[39] Vega-Lopez, M. A., Arenas-Contreras, G., Bailey, M., Gonzalez-Pozos, S., Stokes, C. R., Ortega, M. G., Mondragon-Flores, R. (2001): Development of intraepithelial cells in the porcine small intestine. Dev Immunology, 8, 147-158.

[40] Vitini, E., Alvarez, S., Medina, M., Medici, M., De Budeguer, M. V., Perdigon G. (2001): Gut mucosal immunostimulation by lactic acid bacteria. Biocell, 24, 223232.

[41] Wallace, R. J., Newbold, C. J. (1992): Probiotics for ruminants. In: Probiotics - The scientific basis (Fuller, R. ed.), pp. 317-353. Chapman and Hall, London. 